\title{
Egy kontinens, két témakör és rengeteg lehetőség
}

\author{
Kardos Dorottya \\ ELTE PPK Neveléstudományi Doktori Iskola, doktorandusz hallgatója, \\ Felsőoktatás- és Innovációkutató Csoport tagja \\ kardos.dorottya@ppk.elte.hu
}

Michael Schratz, Hana Červinková, Gábor Halász, Milan Pol, Luís Tinoca (2019). European Doctorate in Teacher Education - Researching Policy and Practice. Wroctaw. ISBN: 978-83-65 408-35-8

DOI: 10.37205/TEL-hun.2020.1-2.08

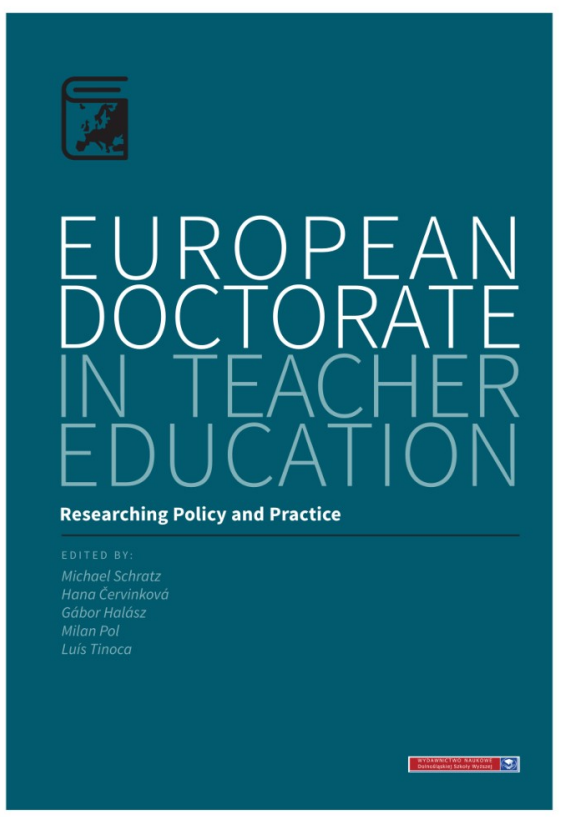

A European Doctorate in Teacher Education - Researching Policy and Practice címü kötet a European Doctorate in Teacher Education (EDiTE) projekt keretében létrejött Horizon 2020 kutatási programot mutatja be, melynek fókuszában a tanárképzés, a tanárok tanulása és a felsőoktatás világa áll. Tagja az Európai Unió által támogatott Marie-Curie Innovatív Tréning Networknek. Az EDiTE projekt fó alapértékei a kollaboráció és a szoros együttműködés az intézmények között. Az EDiTE network öt partneregyetem, az Eötvös Loránd Tudományegyetem (ELTE), a University of Lower Silesia (ULS), University of Lisbon (Ulisboa), University of Innsbruck (UIBK) és a Masaryk University (MU)

összefogásával működik. Az egyetemek közös célként határozzák meg a társadalmi kihívásokra való reflektálást és az innovatív megoldások keresését, szakemberek képzését és kapcsolatteremtést a kutatás, a tanárképzés és a tanulás-tanítás között a gyakorlat és a döntéshozatal területein.

Jelen kötet az EdiTE könyvek sorozatának tagja, melyek olyan témákat dolgoztak fel, mint például a finn tantervi átalakulás, a pedagógiai innovációk bevezetése és hatása Portugáliában vagy a kortárs európai irányzatok megjelenése a magyar tanárképzésben. Különlegessége elődeihez képest, hogy az olvasó nem egy, 
hanem több európai ország helyzetét, kihívásait, újításait ismerheti meg Lengyelországtól Magyarországon át Portugáliáig.

Tizenegy ország tizenöt kiemelkedő eredményeket bemutató doktori kutatása a tanárképzés és a tanári tanulás témái köré csoportosulva változatos képet alkot. A szerzők az oktatás több területéről érkező szakemberek, a partneregyetemek valamelyikén végzik doktori tanulmányaikat. A különböző országok partnerintézményei átfogó képet kívánnak nyújtani a változó európai tanárképzés helyzetéről, intenzív együttműködéssel törekednek a tudásátadás intenzívebbé tételére a minél jobb hallgatói tanulási tapasztalatszerzés érdekében. A mủ létrejöttének alapvetései közé tartozik az a gondolat, hogy a tanárképzés, a tanárok tanulásának alakulása van a legnagyobb hatással a tanulók tanulási sikerességére.

A kötet két nagy részből áll: az első rész bemutatja a konzorciumot és a kutatókat, majd a második rész a tanulmányokat tartalmazza, amelyek mindegyike a tanári tanulás és a tanárképzés témáit dolgozza fel európai kontextusban. Az országok politikai, történelmi és kulturális háttere igen eltérő, a különbségek jól kirajzolódnak, így a könyv gazdag a perspektívák tekintetében, kérdéseket vet fel, és lehetséges válaszokat ajánl az olvasó figyelmébe a tanári mentorrendszer működéséről, a kollaboratív tanulásról, az állampolgári nevelés gyakorlatáról és fontosságáról.

A kötetben az oktatás múltja és jelene is bemutatásra kerül, továbbá az egyes tanulmányok lehetséges innovációkat vizsgálnak meg, melyek között megjelenik a technológia fokozott használata, az értékelési módszerek újraértelmezése és modernizálása, a sikeres integráció érdekében a szülők és a tanulók intenzív bevonása a tanári munkába, illetve az inkluzív szemlélet széleskörủ érvényesítése a tanulói szükségletek hatékony támogatása érdekében.

A tanulmánykötet kutatási módszerek tekintetében igen gazdag. Megjelenik benne többek között az összehasonlító esettanulmány és a dokumentumelemzés, habár a leggyakoribb az interjú valamely formája, például a félig strukturált és a fókuszcsoportos interjú. Az összehasonlító elemzések között több magyar vonatkozású is található. Symeonidis Vasileios azt vizsgálta, hogy milyen hatással voltak az Európában zajló reformok a tanárképzésben szakpolitikai és gyakorlati szempontból. Az összehasonlító esettanulmány Ausztria, Görögország és Magyarország tanárképzésének átalakulásába, a különböző innovatív folyamatok lezajlásába ad betekintést, például a tanári szakmai kompetenciák központi meghatározása Ausztriában hozzájárult a tanári professzió és identitás meghatározásához, 
Magyarországon pedig a tanári életpályamodell szerves részévé vált, míg ez a terület Görögországban a szűkebb szakmai közösségek szintjén maradt.

Helena Kovacs más szempontból mutatja be a tanári kompetencia témakörét Magyarországon és Portugáliában. A két ország sok egyezést mutat ezen a területen, az innovatív iskolákban a tanárok szakmai tanulása hasonlóképpen zajlik. Eredményei arra utalnak, hogy az innovatív tanulási környezetek elősegítik a tanárok kompetenciáinak fejlődését és magasabb szintű oktatási tevékenység végzését.

Pesti Csilla a tanárképzést és a gyakorlati kutatásra való felkészítést vizsgálja két magyar és osztrák egyetem dokumentumainak elemzése, egyéni és csoportos interjúk segítségével. Hasonlóság a két ország esetében, hogy a hallgatók kapcsolatba kerülnek az oktatók kutatásaival, de kihívást jelent számukra a kutatási eredmények integrálása tanítási gyakorlatukba. Továbbá mindkét országban hiányosságokról számoltak be a kutatási gyakorlatra való felkészítésére vonatkozóan.

A témákat tekintve a tanárok tanulásának kutatása kiemelten fontos, mivel a legtöbb esetben a tanárok idejük legnagyobb részét arra fordítják, hogy minél magasabb színvonalon oktassanak, de keveset tudunk arról, hogy mennyi idejük és lehetőségük marad a saját szakmai képzésükre. Paneru Dev Raj tanulmányában olvasható, hogy Csehországban a tanárok a technológiai újításokat széles körben alkalmazzák az angol nyelv oktatása során. Szelei Nikolett munkájából kiderül, hogy Portugáliban az egyre növekvő kulturális diverzitásra a tanárok különböző stratégiákkal válaszolnak, melyeket szervezett workshopokon, gyakran informális tudásátadás keretein belül sajátítanak el.

A tanulmányok másik nagy csoportja a tanárképzés témája köré csoportosul. A tanárképzés reformja egyre nagyobb figyelmet kap Európában. Symeonidis Vasileios tárgyalja Görögország helyzetét, melyet erősen befolyásolt a gazdasági válság. A költségvetés redukálása az oktatás területén azt eredményezte, hogy a törvényalkotás kevéssé fejlődik ezen területen, míg a szükebb tudományos és szakmai csoportok nagy hangsúlyt fektetnek a tanárképzés modernizálására. Arra az esetre, amikor a tanárok extrém szegénységben élő tanulókat oktatnak Tóth Tamás hívja fel a figyelmet, és mutatja be, hogy gyakran olyan elvárásoknak vannak kitéve a tanárok, melyeket abban a környezetben, ahol dolgoznak nem lehet elérni, így nem tudnak a központi normákhoz igazodni. 
Külön kiemelendő pozitívum, hogy az inkluzivitás kérdésköre több tanulmányban is megjelenik a multikulturalizmus, a fogyatékossággal élő tanulók és az oktatási környezet tekintetében is. Wagner Josefine a befogadó szemléletet az oktatás alapelvének tekinti, és hangsúlyozza, hogy a tanárok a változás legfőbb elősegítői. Továbbá mivel az inklúziót a gyakorló pedagógusok alkalmazzák a mindennapokban, a pedagógusképzésnek fel kell őket készítenie nemcsak a fogyatékosság és az egészségügyi problémák, de a multikulturális csoportok és a mélyszegénység pedagógiai következményeinek kezelésére is.

Az EDiTE program keretében egy multikulturális és szakmai szempontból sokszínű közösség jött létre, és ezt a könyv tökéletesen képviseli, melyről összességében elmondható, hogy izgalmas témákat mutat be, problémavilága változatos és aktuális, betekintést ad több ország oktatási rendszerének, tanárképzésének müködésébe, és a gyakorlati szakemberek tanulásának világába. Mindezt olyan szakmai stílusban teszi, ami könnyen befogadható és értelmezhető az olvasó számára.

A könyv elolvasása szakmai segítséget nyújt azoknak, akik az oktatás világát, a tanárképzés, a tanári tanulás témaköreit kutatják, és szeretnének sokféle nézőpontot, problémakört megismerni, kutatási kérdéseikre több európai ország helyzetének megismerésén keresztül válaszokat kapni.

A mű végén az egyes partnerintézmények beszámolói az EDiTE program pozitív hatásairól informálnak, és bizonyítják a nemzetközi összefogás erejét. Az Eötvös Loránd Tudományegyetem nemzetközi doktori iskolája az innováció dinamikus színterévé vált. A University of Lisbon esetében a nemzetköziesedés teret hódított, és megalapították első angol nyelvű programjukat. Szintén a nemzetközi környezet pozitív hatásait emelte ki a University of Innsbruck, mely a nyári egyetemek és konferenciák során kialakult kapcsolati hálót tartja a program egyik legfontosabb eredményének. A Masaryk University pedagógiai karának ez volt az első Horizon 2020-as projektje, és értékesnek tartják az együttműködésből fakadó tanulási lehetőségeket. Végül, a University of Lower Silesia megerősödött hazai és nemzetközi pozícióról és progresszív fejlődésről számolt be. 